\title{
ANALISIS PERILAKU MINAT WISATAWAN BERKUNJUNG KEMBALI KE PULAU SAMOSIR
}

\section{Asianna Martini Simarmata1, Fitri Yani Panggabean ${ }^{2}$, Yonson Pane ${ }^{3}$, Elisabeth Nainggolan ${ }^{4}$}

\author{
STIE Eka Prasetya ${ }^{134}$, Universitas Pembangunan Panca Budi² \\ fitriyani@dosen.pancabudi.ac.id
}

$\underline{\text { Received : } 18 \text { September 2021|Reviewed: 22 September 2021 | Accepted: } 27 \text { September } 2021}$

\begin{abstract}
ABSTRAK
Pulau Samosir merupakan salah satu destinasi wisata unggulan di kawasan Geopark Kaldera Toba. Begitu banyak faktor terkait minat wisatawan berkunjung kembali ke Pulau Samosir. Sehingga penelitian bertujuan untuk membuktikan: 1) pengaruh daya tarik wisata dan kualitas pelayanan terhadap minat berkunjung kembali ke Pulau Samosir; dan 2) pengaruhnya melalui kepuasan pengunjung sebagai intervening. Sebanyak 274 wisatawan lokal memberikan respon pada kuesioner yang disebarkan secara langsung melalui dukungan Dinas Pariwisata Kabupaten Samosir dan mahasiswa. Pengumpulan data meng gunakan kuesioner yang telah valid dan reliabel. Secara berkala tim peneliti mengumpulkan informasi dari para wisatawan yang berkunjung ke Pulau Samosir yang membutuhkan waktu sekitar 2 bulan. Teknik analisis data menggunakan analisis jalur dengan bantuan aplikasi SPSS. Temuan penelitian mengungkapkan bahwa daya tarik wisata, kualitas pelayanan, dan kepuasan pengunjung berpengaruh terhadap minat wisatawan berkunjung kembali ke Pulau Samosir. Kualitas pelayanan merupakan prediktor yang dominan pada model regresi. Namun, kepuasan pengunjung tidak efektif sebagai intervening yang memperkuat minat wisatawan berkunjung kembali. Implikasi makalah ini mengungkapkan bahwa kepuasan pengunjung perlu ditingkatkan dengan menyediakan berbagai fasilitas dan infrastruktur yang mendukung optimasi kualitas pelayanan di Pulau Samosir. Sehingga memberikan efek domino yang positif terhadap peningkatan kunjungan wisawatan ke Pulau Samosir.
\end{abstract}

Kata Kunci: Minat berkunjung kembali, daya tarik, kepuasan, kualitas pelayanan.

\begin{abstract}
Samosir Island is one of the leading tourist destinations in the Toba Caldera Geopark area. So many factors are related to the intention of tourists revisiting Samosir Island. So the research aims to prove: 1) the influence of tourist attraction and service quality on interest in reintention visiting Samosir Island; and 2) its influence through visitor satisfaction as an intervening. A total of 274 local tourists responded to a questionnaire distributed directly with the support of the Tourism Office of Samosir Regency and students. Collected data using a questionnaire that has been valid and reliable. The research team periodically collects information from tourists visiting Samosir Island, which takes
\end{abstract} Korespondensi:

STIE Eka Prasetya ${ }^{1}$, Universitas

Pembangunan Panca Budi ${ }^{2}$

Kota Medan, Sumatera Utara ${ }^{12}$

JURNAL ILMIAH DINAMIKA SOSIAL 5 (2) 2021| 190

E-mail: rizkimaharani456@gmail.com 
abo190ut two months. The data analysis technique uses path analysis with the SPSS application. Research findings reveal that tourist attraction, service quality, and visitor satisfaction affect the reintention of tourists to Samosir Island. Service quality is the dominant predictor in the regression model. However, visitor satisfaction is not effective as an intervention that strengthens the intention of tourists to visit again. The implication of this paper is that visitor satisfaction needs to be improved by providing various facilities and infrastructure that support the optimization of service quality on Samosir Island. Thus providing a domino effect on increasing tourist visits to Samosir Island.

Keywords: reintention, tourist attraction, service quality, visitor satisfaction.

\section{PENDAHULUAN}

Sifat dasar manusia secara alamiah akan berupaya meningkatkan kesejahteraannya baik secara individu maupun berkelompok. Sehingga memiliki keinginan yang searah dengan kesejahteraan ekonomi untuk dapat menikmati keindahan atau panorama alam dari berbagai aspek pariwisata seperti budaya dan adat yang berlaku pada suatu etnik. Akan tetapi, industri pariwisata akan menghadapi kondisi new normal pasca pandemi covid-19. Tergunjangnya aspek ekonomi dikarenakan pandemi menjadi hal yang menarik untuk dikaji pada ind ustri pariwisata. Sisi penawaran dan sisi permintaan pariwisata akan membentuk kesimbangan yang baru dengan memperhatikan sosial-ekonomi-budaya dan protokol kesehatan sebagai newcomers yang perlu diperhatikan oleh pihak pengelola pariwisata. Keseimbangan baru tersebut akan menguji teori keperilakuan wisatawan.

Beberapa para ahli menjelaskan intensi wisatawan untuk mengulangi pengalaman atau berkunjung kembali masih menjadi dinamika teori yang secara dinamis memiliki cara pandang yang berbeda ditinjai dari objek wisata. Perdebatan teori tersebut disebabkan bervariasinya metode, teknik, model, dan berbagai variabel eksogen yang mempengaruhi intensi tersebut (Chung et al., 2015; Duarte Alonso et al., 2015). Keragaman ini menunjukkan model dan variabel predictor yang dikonstruksi para peneliti terdahulu belum mampu diaplikasikan pada semua fenomena yang dapat terjadi. Kondisi tersebut menciptakan celah penelitian yang menginspirasi para penulis untuk mengemukakan model-model alternatif yang komprehensif menjelaskan intensi para wisatawan untuk berkunjung kembali ke Pulau Samosir. Sehingga peneliti memilih Pulau Samosir sebagai unit observasi dengan keragaman wisatawannya, terutama keragaman perilaku wisatawan didalam mempersepsikan daya tarik wisata, kualitas pelayanan, kepuasan wisatawan, dan minat berkunjung kembali.

Beberapa peneliti terdahulu mengungkapkan persepsi kualitas pelayanan, daya tarik wisata, kepuasan wisatawan, merupakan predictor yang baik terhadap perilaku wisatawan untuk berkunjung kembali (Darojat, 2021; Mansour \& Ariffin, 2017). Untuk menarik minat berkunjung wisatawan maka pihak manajemen perusahaan jasa pariwisata harus melakukan strategi pemasaran yang tepat dalam memasarkan barang dan jasa pariwisata serta keunggulan dan kualitas yang dapat bersaing dipasar, sehingga para pengunjung atau konsumen tertarik untuk berkunjung ke tempat pariwisata dan pengunjung merasa puas dengan pelayanan yang disediakan pihak manajemen pariwisata. Tentu kepuasan tersebut akan berdampak pada penguatan keberlangsungan usaha para penyedia jasa pariwisata, seperti kuliner, cinderamata, konveksi, dan usaha kecil lainnya (Panggabean et al., 2018). Sehingga daya tarik, kualitas pelayanan, dan kepuasan pengunjung yang optimal berorientasi pada optimasi pelayanan akan berdampak pada keunggulan bersaing (Dalimunthe, 2017) objek wisata yang pada gilirannya akan meningkatkan kunjungan kembali para wisatawan.

Berdasarkan beberapa kajian tersebut, peneliti menggunakan tiga variabel yang diduga dapat menguji konstruk model pengukuran minat wisatawan berkunjung kembali. Persepsi kualitas pelayanan dan daya tarik wisata merupakan variabel yang pertama yang dipertimbangkan. Berdasarkan berbagai riset terdahulu ditemukan bahwa kedua variabel 
tersebut memiliki hubungan resiprokal yang memiliki efek domino terhadap minat berkunjung kembali (Kaukabilla \& Kholiq, 2020; Ngajow et al., 2021). Sehingga baik buruknya kualitas pelayanan dan daya tarik wisata akan berpengaruh pada kualitas kepuasan wisatawan, dan juga berdampak pada perilaku minatnya untuk berkunjung. Tujuan penelitian untuk: (1) menganalisis pengaruh daya tarik wisata dan kualitas pelayanan terhadap kepuasan pengunjung; dan (2) menganalisis pengaruh daya tarik wisata dan kualitas pelayanan terhadap minat wisatawan berkunjung kembali melalui kepuasan pengunjung sebagai intervening.

\section{KAJIAN TEORI}

\section{Minat Berkunjung Kembali}

Perilaku dalam bentu niat berkunjung sangat erat kaitannya dengan perilaku wisatawan dalam membeli produk-produk yang tersedia di objek wisata. Produk tersebut dapat berupa barang atau jasa yang tersedia maupun disediakan oleh masyarakat lokal untuk memenuhi kepuasan para wisatawan. Fatini dan Dewi (2020) dan Hidayahtullah ddk (2020) menyatakan bahwa persepsi kualitas layanan dan kepuasan telah terbukti menjadi prediktor yang baik dari minat kunjungan kembali pengunjung.

Rohaeni dan Marwa (2018) mengemukakan bahwa persepsi kualitas layanan yang dirasakan merupakan tanggapan kognitif terhadap jasa yang ditawarkan, sedangkan kepuasan secara keseluruhan merupakan respon emosional yg didasarkan pada fenomena pandangan secara menyeluruh. Hal ini juga dikuatkan oleh Septianing dan Farida (2021) yang memberikan dukungan empiris terhadap hubungan antara kualitas dan nilai yang dirasakan. Hasil riset mereka menemukan bahwa pelayanan yang dirasakan merupakan penilaian yang fundamental atas kualitas pelayanan pada objek wisata. Indriastuty dkk (2020) melaporkan bahwa kualitas pelayanan akan meningkatkan persepsi terhadap nilai pelayanan yang dirasakan, dan juga akan memunculkan minat untuk membeli kembali.

Kepuasan pelanggang menjadi evaluasi pelayanan penyedia jasa yang terkait positif dengan minat wisatawan untuk berkunjung kembali, sehingga berpotensi pada keunggulan bersaing objek wisata. Kepuasan pelanggan dapat memberikan beberapa manfaat, di antaranya hubungan antara perusahaan dan pelanggannya menjadi harmonis, memberikan dasar yang baik bagi pembelian ulang dan terciptanya loyalitas pelanggan, serta membentuk suatu rekomendasi dari word-of-mouth yang menguntungkan bagi perusahaan. Kepuasan pelanggan juga memperkuat perilaku terhadap merek dan kemungkian besar akan mengarahkan pada pembelian terhadap merek yang sama.

\section{Kepuasan Pengunjung}

Persepsi atau perasaaan pelanggan atas penyediaan barang dan jasa dapat diperoleh dengan membandingkan kinerja produk yang diterima dengan espektasi yang diharapkan pelanggan, yang disebut juga sebagai kepuasan pelanggan (Kotler et al., 2009). Jika kinerja suatu produk memenuhi atau melebihi ekspektasi dari pelanggan maka akan tercipta rasa puas dan sangat puas pada diri pelanggan. Jika kinerja produk berada dibawah harapan, maka seorang pelanggan akan merasa tidak puas.

Kepuasan merupakan salah satu cara untuk mengukur kinerja organisasi dari aspek non finansial yang efektif terhadap loyalitas pelanggan pada produk yang disediakan, yang mana pada gilirannya akan mencapai kesuksesan pencapaian tujuan organisasi. Terdapat tiga content utama dalam menjelaskan kepuasan pelanggan, yaitu 1) respon emosional dan kognitif dari kepuasan konsumen; 2) respon konsumen diarahkan pada ekspektasi, produk, pola konsumsi, dan pengalaman; 3) respon konsumen setelah menggunakan produk. 
Kepuasan pengunjung merupakan penilaian evaluasi setelah para wisatawan mengkonsumsi produk-produk yang disediakan oleh penyedia jasa atau menikmati panorama alam secara natural. Kepuasan tersebut secara komprehensif menimbulkan perasaan puas atau kecewa atas penyediaan atribut wisata (Samtono \& Ardi, 2021). Hal ini sejalan dengan pendapat Fatini dan Dewi (2020) kepuasan, kepercayaan, dan ketahanan pelanggan memiliki pengaruh yang erat dengan kualitas layanan yang diterima sehingga berdampak positif terhadap pendapatan penyedia jasa wisata.

\section{Daya Tarik Wisata}

Setiap konsumen atau pengunjung memiliki cara yang berbeda dalam menikmati panorama wisata yang ditawarkan. Barang, jasa, budaya, dan keindahan alam yang dimiliki objek wisata menawarkan beragam bentuk daya tarik untuk memikat para pengunjung. Daya tarik wisata memiliki karakteristik yang bersumber dari produk-produk yang ditawarkan yang mengakibatkan penilaian dari pengunjung atas kepuasan yang mereka terima (2019). Pulau Samosir memiliki karakteristik daya tarik wisata alam berupa lereng bukit, danau, dan pemandangan yang memikat para pengunjung. Selain panorama alam, Pulau Samosir juga menyediakan keanekaragaman adat, budaya, dan sejarah raja batak. Sehingga penduduk local memanfaatkan potensi tersebut dengan menyediakan souvernir, pemandu wisata, penginapan, dan kebutuhan pengunjung lainnya. Semakin bervariasi karakteristik daya tarik wisata yang ditawarkan maka semakin banyak produk dalam bentuk barang atau jasa yang dapat menjadi sumber penghasilan masyarakat lokal.

Berbagai peneliti terdahulu telah mengkaji daya tarik wisata dari berbagai aspek. Fasilitas berbentuk sarana dan prasarana yang tersedia dan juga akses menuju objek wisata merupakan salah satu bentuk daya tarik wisata untuk memikat pengunjung (Mansour \& Ariffin, 2017). Penyediaan fasilitas merupakan langkah strategis untuk menciptakan data tarik tersendiri. Walaupun, banyak prasyarat pembangunan fasilitas yang harus dipenuhi agar objek wisata terjaga kelestariannya, terutama wisata alam. Basiya dan Rozak (2012) mengungkapkan bahwa daya tarik objek wisata merupakan suatu dorongan awal bagi wisatawan untuk berkunjung menikmati objek wisata yang disajikan secara natural maupun artificial. Lebih lanjut mereka menjelaskan pengelompokkan daya tarik wisata, yaitu objek wisata alam, objek wisata arsitektur bangunan yang memiliki nilai sejarah, modern, arkeologi, objek wisata yang dikelola secara khusus oleh pemerintah atau lembaga swadaya, objek wisata budaya, dan objek wisata sosial seperti wahana bermain dan berbelanja.

\section{Kualitas Pelayanan}

Prasetio (2012) menjelaskan kond isi dinamis yang saling terkait antara kualitas dengan produk, sumber daya manusia, dan lingkungan yang memberikan pemenuhan yang optimal atau gagal memenuhi ekspektasi yang diharapka. Sementara itu kualitas menurut Kotler dkk (2009) menjelaskan kualitas yang bermuara pada konsumen. Jika penyedia jasa wisata mampu memenuhi ekspektasi para wisatawan dari kualitas produk wisata, maka akan berdampak pemenuhan kepuasan wisatawan.

Dalam bidang jasa, diperlukan pelayanan kepada pelanggan yang dapat menyenangkan atau memuaskan pelanggan. Mengacu pada pelayanan tersebut, maka tingkat kualitas pelayanan yang baik akan selalu dilihat dan diukur dari sisi konsumen serta pemenuhan kepuasannya akan suatu pelayanan yang diterimanya.Selanjutnya, kualitas ini mempengaruhi kesan konsumen terhadap suatu produk dan kesan ini akan berd ampak pada proses dari kualitas yang diharapkan terhadap kualitas yang dirasakan. 
Kualitas pelayanan (service quality) dapat diukur dengan menggunakan lima dimensi yaitu; reliability, responsiveness, assurance, empathy, dan tangibles (Alaan, 2016). Dimensidimensi tersebut menciptakan kreasi dalam menghadapi rintangan, meningkatkan loyalitas pelanggan, dan juga menekan efisiensi biaya bagi organisasi.

\section{METODE PENELITIAN}

Penelitian kuantitatif dengan pendekatan eksplanatory digunakan pada riset ini. Sumber data berjenis primer yang diperoleh langsung dari para repsonden wisatawan lokal yang berkunjung ke Pulau Samosir. Penelitian ini menggunakan variabel eksogen (daya tarik wisatawan dan kualitas pelayanan), variabel endogen (minat berkunjung kembali), dan variabel intervening (kepuasan pengunjung) yang digunakan untuk mengeksplorasi perilaku wisatawan terkait minat berkunjung kembali ke Pulau Samosir.

Pengumpulan data menggunakan kuesioner yang telah melalui verifikasi pengujian kualitas instrumen dengan teknik validitas dan reliabilitas. Kuesioner terdiri dari 4 (empat) bagian yaitu kuesioner daya tarik wisata, kualitas pelayanan, kepuasan pengunjung, dan minat berkunjung kembali yang ditujukan untuk menggali persepsi para wisatawan terkait perilaku minat wisatawan berkunjung kembali ke Pulau Samosir. Pengumpulan data melibatkan Dinas Pariwisata Kabupaten Samosir dan mahasiswa dari STIE Eka Prasetya dan Universitas Pembangunan Panca Budi. Dibutuhkan waktu sekitar 2 (dua) bulan untuk mengumpulkan data yang berjumlah 274 responden yang merupakan wisatawan lokal yang berasal dari berbagai daerah di Ind onesia, yang mana data tersebut kredibel untuk dilanjutkan ke tahap analisis data.

Teknik analisis data menggunakan analisis jalur untuk menguji tujuan penelitian yang dijelaskan pada bagian pendahuluan. Analisis data menyediakan dua model struktur persamaan regresi, yang mana model struktur pertama akan menguji tujuan penelitian pertama dan model struktur kedua akan menguji tujuan penelitian kedua. Nilai koefisien jalur secara langsung dan tidak langsung merupakan sumber informasi utama untuk menguji efektivitas kepuasan pengunjung sebagai variabel intervening yang diharapkan dapat meningkatkan pengaruh antara variabel eksogen dan endogen (Ghozali, 2013).

\section{PEMBAHASAN}

Temuan penelitian dari 274 responden wisatawan lokal yang berkunjung ke Pulau Samosir menunjukkan bahwa nilai rerata variabel minat berkunjung kembali $(114,01)$ merupakan yang tertinggi diikuti oleh variabel, kepuasan berkunjung $(112,62)$, kualitas pelayanan $(112,57)$, dan daya tarik wisata $(111,43)$ secara berurutan (lihat Tabel 1). Selanjutnya korelasi antar variabel ditemukan bahwa hubungan yang terkuat terdapat pada korelasi antara kepuasan pengunjung dengan minat berkunjung kembali $(0,982)$. Temuan ini memberikan informasi bahwa terdapat hubungan yang erat antara kepuasan yang diterima pengunjung dengan minat mereka untuk berkunjung kembali, baik dari fasilitas dan infrastruktur. Hal ini mendukung temuan riset-riset terdahulu yang menjelaskan bahwa kepuasan pengunjung merupakan aspek urgen yang terus dioptimalkan oleh penyedia jasa wisata melalui berbagai penyediaan penginapan, transportasi, dan infrastruktur fisik lainnya (Diarta \& Sarjana, 2020; Rohaeni \& Marwa, 2018). 
Selain itu, korelasi kualitas pelayanan dengan minat berkunjung kembali juga menunjukkan nilai yang positif $(0,929)$. Hal ini memberikan informasi bahwa kualitas pelayanan yang diberikan oleh penyedia jasa di Pulau Samosir diterima dengan baik oleh para responden. Beberapa cendikiawan telah melakukan berbagai riset terkait korelasi tersebut (Darojat, 2021; Indriastuty et al., 2020; Septianing \& Farida, 2021), yang mana temuan pada riset ini mendukung riset-riset yang telah diungkapkan para peneliti terdahulu.

Selanjutnya, diungkapkan temuan terakhir terkait korelasi antara daya tarik wisata dengan minat berkunjung kembali yang menunjukkan nilai positif $(0,916)$ sebagaimana dengan korelasi lainnya yang telah diuraikan. Walaupun menunjukkan nilai korelasi yang paling kecil jika dibandingkan dengan nilai korelasi lainnya, namun nilai korelasi daya tarik wisata dengan minat berkunjung kembali merupakan kategori hubungan yang sangat kuat (Indriastuty et al., 2020; Ngajow et al., 2021). Temuan korelasi ini sejalan dengan berbagai riset-riset terdahulu (Ayuningtyas \& Nugraha, 2021; Darojat, 2021; Indriastuty et al., 2020; Ngajow et al., 2021). Eksplorasi produk unggulan baik bersifat penyediaan barang atau jasa sangat terkait dengan potensi yang dimiliki suatu daerah (Panggabean et al., 2020). Potensi tersebut dapat menjadi daya tarik wisata pada Pulau Samosir yang memiliki ragam karakter diantara keindahan Geopark Kaldera Toba, budaya batak, dan artefak raja batak. Ragam karakter tersebut merupakan ciri khas yang menjadi daya tarik destinasi unggulan yang tidak dimiliki objek wisata alam dan budaya lainnya di Indonesia bahkan diberbagai negara lainnya. Nilai korelasi secara lengkap dapat dilihat pada Tabel 2.

Tabel 1

Statistik Deskriptif

\begin{tabular}{lrrr}
\hline & Mean & Std. Deviation & N \\
\hline Minat Berkunjung Kembali & 114,01 & 10,742 & 274 \\
Daya Tarik Wisata & 111,43 & 10,833 & 274 \\
Kualitas Pelayanan & 112,57 & 9,765 & 274 \\
Kepuasan Pengunjung & 112,62 & 10,943 & 274 \\
\hline
\end{tabular}

Tabel 2

Korelasi antar Variabel

\begin{tabular}{llr}
\hline & & Minat Berkunjung Kembali \\
\hline Pearson & Daya Tarik Wisata &, 916 \\
Correlation & Kualitas Pelayanan &, 929 \\
& Kepuasan Pengunjung &, 982 \\
\hline Sig. & Daya Tarik Wisata &, 000 \\
$(1-$ tailed $)$ & Kualitas Pelayanan &, 000 \\
& Kepuasan Pengunjung &, 000 \\
\hline
\end{tabular}

\section{Pengaruh Daya Tarik Wisata dan Kualitas Pelayanan terhadap Kepuasan Pengunjung}

Pengujian analisis data pada model struktur pertama menghasilkan nilai $R$ Square sebersar 0,965 yang bermakna variabel prediktor daya tarik wisata dan kualitas pelayanan memberikan kontribusi sebesar 96,5\% terhadap kepuasan pengunjung pada model struktur pertama. Sedangkan sisanya dipengaruhi oleh prediktor lainnya diluar model (lihat Tabel 3). 
Tabel 3

Ringkasan Model Struktur 1

\begin{tabular}{lrrrrr}
\hline Model & R & R Square & $\begin{array}{r}\text { Adjusted R } \\
\text { Square }\end{array}$ & $\begin{array}{r}\text { Std. Error of the } \\
\text { Estimate }\end{array}$ & $\begin{array}{r}\text { Durbin- } \\
\text { Watson }\end{array}$ \\
\hline 1 &, $983^{\mathrm{a}}$ &, 965 &, 965 & 2,044 & 2,069 \\
\hline
\end{tabular}

a. Predictors: (Constant), Daya Tarik Wisata, Kualitas Pelayanan

b. Dependent Variable: Kepuasan Pengunjung berikut.

Berdasarkan nilai koefisien struktur pertama, maka diperoleh model regresi [1] sebagai

$\mathbf{Y}=\mathbf{a}+\mathbf{b}_{1} \mathbf{X}_{1}+\mathbf{b}_{2} \mathbf{X}_{2}+\mathbf{e} \quad \rightarrow \quad$ persamaan model regresi struktur pertama [1] Kepuasan Pengunjung $=-10,714+0,104$ Daya Tarik Wisata $+0,885$ Kualitas Pelayanan $+\mathrm{e}$

Persamaan model regresi struktur pertama menjelaskan bahwa daya tarik wisata memberikan kontribusi sebesar 0,104 poin secara positif dan kualitas pelayanan memberikan kontribusi sebesar 0,885 poin terhadap kepuasan pengunjung ke Pulau Samosir. Berdasarkan nilai koefisien tersebut diketahui bahwa kualitas pelayanan memberikan kontribusi yang lebih besar terhadap kepuasan pengunjung, jika dibandingkan dengan daya tarik wisata. Informasi ini sejalan dengan berbagai riset yang telah ditemukan (Hidayatullah et al., 2020; Ind riastuty et al., 2020; Kaukabilla \& Kholiq, 2020; Prasetio, 2012). Kualitas pelayanan memainkan peran penting terhadap kepuasan pengunjung. Para penyedia jasa wisata memberikan pelayanan yang optimal seperti keterandalan informasi budaya (reliability), responsif (responsiveness), dan empati (empathy) (Rosita et al., 2016).

Selanjutnya temuan dari pengujian tujuan penelitian pertama menunjukkan bahwa terdapat pengaruh daya tarik wisata dan kualitas pelayanan terhadap kepuasan pengunjung ke Pulau Samosir. Hal ini dibuktikan dari nilai signifikansi lebih kecil dari alpha $(0,05)$ dan nilai t dari daya tarik wisata $(3,322)$ dan kualitas pelayanan $(28,410)$ lebih besar dari t tabel (lihat Tabel 4).

Tabel 4

Nilai Koefisien Struktur 1

\begin{tabular}{llrrrrr}
\hline Model & \multicolumn{2}{c}{$\begin{array}{c}\text { Unstandardized } \\
\text { Coefficients }\end{array}$} & \multicolumn{2}{c}{ Standardized } & & \\
& & Coefficients & t & Sig. \\
\cline { 2 - 7 } & & Std. Error & Beta & & \\
\hline 1 & (Constant) & $-10,714$ & 1,440 & & $-7,443$ &, 000 \\
& Daya Tarik Wisata &, 105 &, 031 &, 104 & 3,322 &, 001 \\
& Kualitas Pelayanan &, 992 &, 035 &, 885 & 28,410 &, 000 \\
\hline
\end{tabular}

a. Dependent Variable: Kepuasan Pengunjung

Hasil penelitian ini sejalan dengan berbagai riset terdahulu (Darojat, 2021; Ind riastuty et al., 2020; Kaukabilla \& Kholiq, 2020). Kaukabilla dan Kholiq (2020) menjelaskan temuan risetnya bahwa daya tarik wisata merupakan stimulus awal yang mempengaruhi wisatawan berkunjung ke objek wisata tersebut. Berbagai keunikan yang melekat pada objek wisata seperti panorama alam, budaya, sejarah, artefak, dan objek wisata buatan memberikan fenomena tersendiri yang akan menimbulkan daya tarik para wisatawan untuk berkunjung. Selanjutnya, ketersediaan fasilitas dan infrastruktur fisik (tangible) dan non fisik (non tangible) 
akan memberikan respon umpan balik atas kepuasan yang dirasakan pengunjung. Secara major, jika wisatawan menerima kualitas pelayanan secara positif yang diberikan penyedia jasa, maka akan meningkatkan kepuasan pengunjung yang akan memberikan peluang bagi wisatawan untuk berkunjung kembali ke Pulau Samosir. Namun sebaliknya, jika kualitas pelayanan yang dirasakan buruk oleh pengunjung maka akan menurunkan kepuasan pengunjung. Oleh karena itu, daya tarik dan kualitas pelayanan merupakan aspek urgen yang bersifat resiprokal mendukung kepuasan pengunjung.

\section{Pengaruh Daya Tarik Wisatawan dan Kualitas Pelayanan terhadap Minat Berkunjung Kembali Melalui Kepuasan Pengunjung Sebagai Intervening}

Temuan selanjutnya, mengungkapkan bahwa daya tarik wisata, kualitas pelayanan, dan kepuasan pengunjung memiliki pengaruh simultan terhadap minat berkunjung kembali ke Pulau Samosir. Hal ini dibuktikan dari nilai signifikansi 0,000 lebih kecil dari alpha $(0,05)$ dan nilai $\mathrm{F}$ hitung sebesar 524,651 yang lebih besar dari nilai $\mathrm{F}$ tabel (lihat Tabel 5). Selanjutnya, kontribusi variabel prediktor terhadap variabel endogen sebesar 0,854 . Hal ini bermakna bahwa daya tarik wisata, kualitas pelayanan, dan kepuasan pengunjung berkontribusi terhadap minat berkunjung kembali sebesar $85,4 \%$, sedangkan sisanya dipengaruhi oleh prediktor lain diluar model regresi (lihat Tabel 6).

Tabel 5

Anova

\begin{tabular}{lrrrrr}
\hline Model & Sum of Squares & df & Mean Square & F & Sig. \\
\hline 1 Regression & 26888,449 & 3 & 8962,816 & 524,651 &, $000^{\mathrm{a}}$ \\
Residual & 4612,519 & 270 & 17,083 & & \\
Total & 31500,967 & 273 & & & \\
\hline
\end{tabular}

a. Predictors: (Constant), Daya Tarik Wisata, Kualitas Pelayanan, Kepuasan Pengunjung

b. Dependent Variable: Minat Berkunjung Kembali

Tabel 6

Ringkasan Model Struktur 2

\begin{tabular}{lrrrrr}
\hline Model & $\mathrm{R}$ & $\mathrm{R}$ Square & Adjusted R Square & $\begin{array}{r}\text { Std. Error of the } \\
\text { Estimate }\end{array}$ & $\begin{array}{r}\text { Durbin- } \\
\text { Watson }\end{array}$ \\
\hline 1 &, $924^{\mathrm{a}}$ &, 854 &, 852 & 4,133 & 1,962 \\
\hline
\end{tabular}

a. Predictors: (Constant), Daya Tarik Wisata, Kualitas Pelayanan, Kepuasan Pengunjung

b. Dependent Variable: Minat Berkunjung Kembali

Berdasarkan informasi pada Tabel 7 diperoleh model regresi struktur kedua [2], yaitu:

$\mathbf{Y}=\mathbf{a}+\mathbf{b}_{1} \mathbf{X}_{1}+\mathbf{b}_{2} \mathbf{X}_{2}+\mathbf{b}_{3} \mathbf{X}_{\mathbf{3}}+\mathbf{e} \quad \rightarrow \quad$ persamaan model regresi struktur kedua [2] Minat Berkunjung Kembali $=4,481+0,178$ Daya Tarik Wisata $+0,451$ Kualitas Pelayanan + 0,308Kepuasan Pengunjung $+\mathrm{e}$

Informasi pada model regresi struktur kedua diketahui bahwa kualitas pelayanan merupakan prediktor yang dominan mempengaruhi minat wisatawan berkunjung kembali ke Pulau Samosir. Hal ini dibuktikan dengan nilai koefisien kualitas pelayanan sebesar 0,451. Hal ini sejalan dengan riset-riset yang telah diungkapkan para peneliti sebelumnya (Diarta \& Sarjana, 2020; Fatini \& Dewi, 2020). Kualitas pelayanan memberikan pengaruh yang positif terhadap minat wisatawan berkunjung kembali. Kualitas pelayanan yang diberikan penyedia 
jasa dapat berupa tangible dan intangible yang memberikan kesan yang baik, sehingga berdampak pada minat berkunjung kembali. Demikian juga dengan prediktor lainnya, seperti kepuasan pengunjung $(0,308)$ dan daya tarik wisata $(0,178)$ yang juga memiliki pengaruh positif terhadap minat berkunjung kembali ke Pulau Samosir.

Tabel 7

Nilai Koefisien Struktur 2

\begin{tabular}{llrrrrr}
\hline Model & \multicolumn{2}{c}{$\begin{array}{l}\text { Unstandardized } \\
\text { Coefficients }\end{array}$} & \multicolumn{2}{c}{$\begin{array}{c}\text { Standardized } \\
\text { Coefficients }\end{array}$} & & \\
\cline { 2 - 5 } & B & Std. Error & Beta & t & Sig. \\
\cline { 2 - 5 } & (Constant) & 4,481 & 3,195 & & 1,402 &, 162 \\
& Daya Tarik Wisata &, 177 &, 065 &, 178 & 2,721 &, 007 \\
& Kualitas Pelayanan &, 496 &, 141 &, 451 & 3,521 &, 001 \\
& Kepuasan Pengunjung &, 302 &, 123 &, 308 & 2,457 &, 015 \\
\hline
\end{tabular}

a. Dependent Variable: Minat Berkunjung Kembali

Temuan pengaruh simultan ini mendukung berbagai riset-riset yang telah ditemukan peneliti terdahulu (Darojat, 2021; Ngajow et al., 2021; Septianing \& Farida, 2021; Tastri et al., 2020). Nilai koefisien pada Tabel 7 memberikan informasi jalur pada masing-masing variabel eksogen ke endogen. Disajikan secara grafis pada Gambar 1.

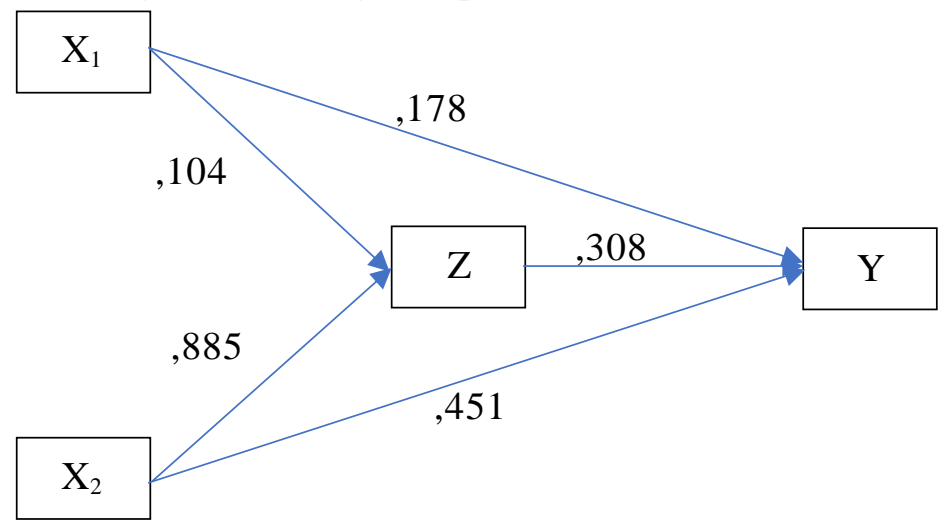

Gambar 1

Diagram Analisis Jalur

Diagram analisis jalur digunakan untuk memudahkan mengetahui pengaruh langsung, pengaruh tidak langsung dan pengaruh total. Nilai-nilai koefisien regresi disusun secara sistematis pada Tabel 8 untuk mengetahui efektivitas variabel intervening dan kontribusi pengaruh antar variabel eksogen ke endogen.

Tabel 8

Rekapitulasi Nilai Koefisien Jalur

\begin{tabular}{lrrrrr}
\hline & \multicolumn{2}{c}{ Direct } & Indirect & \multicolumn{2}{c}{ Total } \\
\cline { 2 - 3 } \cline { 5 - 7 } & $\mathrm{Z}$ & $\mathrm{Y}$ & & $\mathrm{Z}$ & \multicolumn{1}{c}{$\mathrm{Y}$} \\
\hline Daya Tarik $\left(\mathrm{X}_{1}\right)$ & 0,104 & 0,178 & 0,032 & 0,104 & 0,210 \\
\hline Kualitas Pelayanan $\left(\mathrm{X}_{2}\right)$ & 0,885 & 0,451 & 0,273 & 0,178 & 0,724 \\
\hline Kepuasan Pengunjung $(\mathrm{Z})$ & - & 0,308 & - & - & 0,308 \\
\hline
\end{tabular}


Berdasarkan informasi pada Tabel 8, diperoleh nilai pengaruh tidak langsung daya tarik terhadap minat wisatawan berkunjung kembali melalui kepuasan pengunjung sebesar 0,032. Nilai koefisien tersebut lebih kecil dari koefisien regresi pengaruh langsung daya tarik wisata terhadap minat wisatawan berkunjung kembali sebesar 0,178. Hal ini bermakna bahwa kepuasan pengunjung tidak efektif sebagai intervening pengaruh antara daya tarik terhadap minat wisatawan berkunjung kembali.

Begitu juga pada pengaruh kualitas pelayanan terhadap minat wisatawan berkunjung kembali melalui kepuasan pengunjung, yang mana nilai pengaruh tidak langsung sebesar 0,273 lebih kecil dari nilai pengaruh langsung sebesar 0,451. Hal ini membuktikan bahwa kepuasan pengunjung tidak efektif sebagai intervening pengaruh antara kualitas pelayanan terhadap minat wisatawan berkunjung kembali.

Walaupun pengujian korelasi dan regresi menunjukkan bahwa kepuasan pengunjung berkontribusi dan berpengaruh terhadap minat berkunjung kembali. Namun, kepuasan pengunjung tidak efektif sebagai intervening yang diharapkan dapat meningkatkan minat wisatawan berkunjung kembali ke Pulau Samosir. Temuan ini tidak sejalan dengan berbagai riset-riset minat wisatawan yang telah diteliti sebelumnya (Darojat, 2021; Indriastuty et al., 2020; Tastri et al., 2020). Akan tetapi, temuan ini memberikan ruang baru yang menarik untuk diteliti lebih lanjut secara mendalam dan komprehensif terkait tidak efektifnya kepuasan pengunjung sebagai intervening. Tentu saja, kajian riset ini telah memberikan keterbaharuan yang mendukung perkembangan ilmu pengetahuan dibidang pariwisata.

\section{KESIMPULAN}

Berbagai objek destinasi tersedia secara natural seperti fenomena alam, budaya batak, dan artefak raja batak yang menjadikan magnet bagi wisatawan untuk berkunjung ke Pulau Samosir. Temuan penelitian telah membuktikan bahwa daya tarik wisata, kualitas pelayanan, dan kepuasan pengunjung memiliki pengaruh yang positif terhadap minat wisatawan berkunjung kembali. Temuan ini telah diuraikan secara detail dan di dukung oleh riset dan publikasi yang relevan dan kredibel dari berbagai peneliti terdahulu. Riset ini memberikan implikasi penguatan secara konsisten pada kualitas pelayanan yang terbukti secara dominan mempengaruhi minat wisatawan berkunjung kembali ke Pulau Samosir. Namun, ditemukan bahwa kepuasan pengunjung tidak efektif sebagai intervening yang diharapkan dapat meningkatkan minat wisatawan berkunjung kembali ke Pulau Samosir. Temuan ini secara dinamis memberikan peluang bagi riset selanjutnya untuk menggali informasi yang lebih mendalam dan komprehensif terkait kepuasan pengunjung yang gagal sebagai pemoderasi antara daya tarik wisata dan kualitas pelayanan terhadap minat berkunjung kembali.

\section{DAFTAR PUSTAKA}

Alaan, Y. (2016). Pengaruh Service Quality (Tangible, Empathy, Reliability, Responsiveness dan Assurance) terhadap Customer Satisfaction: Penelitian pada Hotel Serela Bandung. Jurnal Manajemen Maranatha, 15(2).

Ayuningtyas, L. S., \& Nugraha, H. S. (2021). Pengaruh E-Word.Of.Mouth, Lokasi, Dan Daya 
Tarik Wisata Terhadap Kepuasan Pengunjung Dengan Keputusan Berkunjung Sebagai Variabel Intervening (Studi Kasus Pada Pantai Menganti Kebumen). Jurnal Ilmu $\begin{array}{lll}\text { Administrasi } \quad \text { Bisnis, } & \text { 652-663), }\end{array}$ https://ejournal3.undip.ac.id/index.php/jiab/article/view/29026

Basiya, R., \& Rozak, H. A. (2012). Kualitas daya tarik wisata, kepuasan dan niat kunjungan kembali wisatawan mancanegara di Jawa Tengah. Jurnal Ilmiah Dinamika Kepariwisataan, 11(2).

Chung, N., Han, H., \& Joun, Y. (2015). Tourists' intention to visit a destination: The role of augmented reality (AR) application for a heritage site. Computers in Human Behavior, 50, 588-599. https://d oi.org/https://doi.org/10.1016/j.chb.2015.02.068

Dalimunthe, M. B. (2017). Keunggulan Bersaing Melalui Orientasi Pasar dan Inovasi produk. Jurnal Konsep Bisnis Dan Manajemen. https://doi.org/https://doi.org/10.31289/jkbm.v3i2.357

Darojat, I. (2021). Analisis Pengaruh Daya Tarik Wisata dan Kualitas Pelayanan Terhadap Minat Berkunjung Ulang Dengan Kepuasan Pengunjung Sebagai Variabel Intervening (Studi Pada Citra Raya Water World). Dynamic Management Journal, 5(1), 23-37. https://doi.org/http://dx.doi.org/10.31000/dmj.v5i1.4101

Diarta, I. K. S., \& Sarjana, I. M. (2020). Pengaruh atribut dan kualitas layanan terhadap kepuasan pengunjung daya tarik wisata pertanian subak di Kota Denpasar Bali. Media Konservasi, 25(2), 113-123. https://doi.org/https://doi.org/10.29244/medkon.25.2.113 123

Duarte Alonso, A., Sakellarios, N., \& Pritchard, M. (2015). The theory of planned behaviour in the context of cultural heritage tourism. Journal of Heritage Tourism, 10(4), 399-416. https://doi.org/https://doi.org/10.1080/1743873X.2015.1044992

Fatini, N. A., \& Dewi, R. S. (2020). Pengaruh kualitas produk dan kualitas pelayanan terhadap kepuasan pengunjung wisata Vanaprastha Gedong Songo Park Kabupaten Semarang. $\begin{array}{llll}\text { Jurnal Ilmu Administrasi Bisnis, } & \text { 9(1), }\end{array}$ https://ejournal3.undip.ac.id/index.php/jiab/article/view/26229

Ghozali, I. (2013). Aplikasi Analisis Multivariate Dengan Program IBM SPSS 21 Update PLS Regresi (Ketujuh). Badan Penerbit Universitas Diponegoro.

Giese, J. L., \& Cote, J. A. (2000). Defining consumer satisfaction. Academy of Marketing Science Review, 1(1), 1-22.

Handayani, S., Wahyudin, N., \& Khairiyansyah, K. (2019). Fasilitas, Aksesibilitas Dan Daya Tarik Wisata Terhadap Kepuasan Wisatawan. Jurnal Ilmiah Manajemen Dan Bisnis, 20(2), 123-133. https://doi.org/http://dx.doi.org/10.30596\%2Fjimb.v20i2.3228

Hidayatullah, S., Rachmawati, I. K., Aristanto, E., Waris, A., \& Patalo, R. G. (2020). Peran Sistem Informasi Pemasaran, Kualitas Pelayanan dan Entrepreneurial marketing serta 
Kepuasan Terhadap Loyalitas Generasi Milenial Berkunjung ke Tempat Wisata. Jurnal Ilmiah Bisnis Dan Ekonomi Asia, 14(1), 74-83. https://doi.org/https://doi.org/10.32812/jibeka.v14i1.184

Indriastuty, N., Saputro, W. E., \& Sukimin, S. (2020). Analisis Daya Tarik Wisata, Persepsi Harga, dan Kualitas Pelayanan terhadap Minat Berkunjung Ulang dengan Kepuasan Konsumen sebagai Variabel Intervening: (Studi pada Pantai Manggar Segara Sari Balikpapan). Jurnal GeoEkonomi, 11(1), 56-73. https://doi.org/https://doi.org/10.36277/geoekonomi.v11i1.108

Kaukabilla, A. P., \& Kholiq, A. (2020). Pengaruh Kualitas pelayanan dan pengemasan daya tarik wisata terhadap kepuasan wisatawan di Ngebel Ponorogo. Jurnal Sosiologi Reflektif, 14(2), 407-424. https://doi.org/https://doi.org/10.14421/jsr.v14i2.1836

Kawatu, V. S., Mandey, S. L., \& Lintong, D. C. A. (2020). Pengaruh Daya Tarik Wisata terhadap Niat Kunjungan Ulang dengan Kepuasan sebagai Variabel Intervening pada Tempat Wisata Bukit Kasih Kanonang. Jurnal EMBA: Jurnal Riset Ekonomi, Manajemen, Bisnis Dan Akuntansi, 8(3), 400-410. https://doi.org/https://doi.org/10.35794/emba.v8i3.30221

Kotler, P., Keller, K. L., Koshy, A., \& Jha, M. (2009). Creation customer value satisfaction and loyalty. Marketing Management, 13, 120-125.

Mansour, J. S. A., \& Ariffin, A. A. M. (2017). The effects of local hospitality, commercial hospitality and experience quality on behavioral intention in cultural heritage tourism. Journal of Quality Assurance in Hospitality I\& Tourism, 18(2), 149-172. https://doi.org/https://doi.org/10.1080/1528008X.2016.1169474

Ngajow, M. T., Tawas, H. N., \& Djemly, W. (2021). Pengaruh Daya Tarik Wisata dan Citra Objek Wisata terhadap Minat Berkunjung pada Objek Wisata Bukit Kasih Kanonang, dengan Pandemi Covid 19 sebagai Variabel Moderator. Jurnal EMBA: Jurnal Riset Ekonomi, Manajemen, Bisnis Dan Akuntansi, 9(2), 92-100. https://doi.org/https://doi.org/10.35794/emba.9.2.2021.33280

Panggabean, F. Y., Dalimunthe, M. B., Aprinawati, A., \& Napitupulu, B. (2018). Analisis Literasi Keuangan Terhadap Keberlangsungan Usaha Kuliner Kota Medan. Jurnal Manajemen Dan Keuangan. https://doi.org/10.33059/jmk.v7i2.872

Panggabean, F. Y., Putri, N. A., Siregar, M., \& Dalimunthe, M. B. (2020). Eksplorasi Produk Unggulan Desa Tomok. Jurnal Penelitian Dan Pengabdian Kepada Masyarakat UNSIQ, 7(2), 139-142. https://doi.org/https://doi.org/10.32699/ppkm.v7i2.783

Prasetio, A. (2012). Pengaruh kualitas pelayanan dan harga terhadap kepuasan pelanggan. Management Analysis Journal, $1(1), \quad$ 1-8. https://doi.org/https://doi.org/10.15294/maj.v1i1.497

Rohaeni, H., \& Marwa, N. (2018). Kualitas Pelayanan Terhadap Kepuasan Pelanggan. Jurnal Ecodemica, 2(2), 312-318. https://doi.org/https://doi.org/10.31294/jeco.v2i2.4503 
Rosita, R., Marhanah, S., \& Wahadi, W. H. (2016). Pengaruh Fasilitas Wisata Dan Kualitas Pelayanan Terhadap Kepuasan Pengunjung Di Taman Margasatwa Ragunan Jakarta. Jurnal Manajemen Resort Dan Leisure, 13(1), 61-72. https://doi.org/https://doi.org/10.17509/jurel.v13i1.2134

Samtono, \& Ardi, R. P. (2021). Strategi Meningkatkan Kepuasan Pengunjung Obyek Wisata Bukit Cinta Banyubiru Kabupaten Semarang. Media Wisata, 19(1), 109-118. https://doi.org/https://doi.org/10.36276/mws.v19i1.71

Septianing, A. D., \& Farida, N. (2021). Pengaruh Fasilitas Wisata Dan Kualitas Pelayanan Terhadap Niat Berkunjung Kembali Melalui Kepuasan Pengunjung (Studi Obyek Wisata Goa Kreo Kota Semarang). Jurnal Ilmu Administrasi Bisnis, 10(1), 781-792. https://ejournal3.undip.ac.id/index.php/jiab/article/view/29796

Tastri, Y. Y., Rahadhini, M. D., \& Triastity, R. (2020). Pengaruh Eksperiental Marketing terhadap Minat Berkunjung Ulang dengan Kepuasan Pengunjung sebagai Variabel Mediasi (Survei pada Pengunjung Taman Pelangi Jurug Surakarta). JURNAL EKONOMI $D A N$ KEWIRAUSAHAAN, 19(1),

92-105. http://ejurnal.unisri.ac.id/index.php/Ekonomi/article/view/3953 